\title{
Hepatoprotective activity of Pterocarpus santalinus L.f., an endangered medicinal plant
}

\author{
B.K. Manjunatha
}

\begin{abstract}
Objective: To evaluate the hepatoprotective activity of crude aqueous and ethanol stem bark extracts of Pterocarpus santalinus (Fabaceae) using $\mathrm{CCl}_{4}$ induced hepatic damage in male Wistar albino rats.

Materials and Methods: The aqueous $(45 \mathrm{mg} / \mathrm{ml})$ and ethanol $(30 \mathrm{mg} / \mathrm{ml})$ extracts of stem bark in $1 \%$ gum tragacanth was administered orally for 14 days and the hepatoprotective activity studied in $\mathrm{CCl}_{4}$ induced hepatic damage model. The hepatoprotective activity was assessed using various biochemical parameters like serum bilirubin, protein, alanine transaminase, aspartate transaminase and alkaline phosphatase along with histopathological studies of liver tissue. Results: There was a significant increase in serum levels of bilirubin, alanine transaminase, aspartate transaminase and alkaline phosphatase with a decrease in total protein level, in the $\mathrm{CCl}_{4}$ treated animals, reflecting liver injury. In the aqueous and ethanol extracts treated animals there was a decrease in serum levels of the markers and significant increase in total protein, indicating the recovery of hepatic cells. Histological study of aqueous extract treated group exhibited moderate accumulation of fatty lobules and cellular necrosis where as ethanol extract treated animals revealed normal hepatic cords without any cellular necrosis and fatty infiltration.

Conclusion: The ethanol and aqueous stem bark extract of $P$. santalinus afforded significant protection against $\mathrm{CCl}_{4}$ induced hepatocellular injury.
\end{abstract}

Received:31.3.2005

Revised: 29.8.2005

Accepted: 18.9.2005

Correspondence to: B.K. Manjunatha E-Mail:

KEY WORDS: $\mathrm{CCl}_{4}$, red sander, stem bark extract.

\section{Introduction}

Pterocarpus santalinus L.f. (Fabaceae) is commonly called as Red sander (English), Kempu honne (Kannada) and Raktachandan (Sanskrit). It is an endangered plant species, endemic to the state of Andrapradesh in India. ${ }^{[1]}$ The plant is renowned for its characteristic timber of exquisite color, beauty and superlative technical qualities and ranks among the finest luxury in Japan. ${ }^{[2]}$ Wood is used as astringent, tonic, as external application for wounds, cuts and inflammations, in treating headache, skin diseases, fever, boils, scorpion sting and to improve sight. ${ }^{[3]}$ The red wood yields a natural dye santalin which is used as a coloring agent in pharmaceutical preparations, food stuffs; fruit extract is used as astringent, diaphoretic, in inflammations, headache, skin diseases, bilious infections and chronic dysentry. ${ }^{[4]}$ Heart wood is known to possess isoflavone glucosides, ${ }^{[5]-[7]}$ savinin, calocedrin ${ }^{[8]}$ and triterpene. ${ }^{[9]}$ The lignan isolated from the heartwood is known to inhibit tumor necrosis factor-alpha production and T-cell proliferation. ${ }^{[8]}$ Ethanolic stem bark extract is known to possess antihyperglycemic activity. ${ }^{[10]}$
The tribal groups of Western Ghats, Shimoga region use stem bark extract of Pterocarpus santalinus in treating diabetes, fever, snake bite and jaundice (About $100 \mathrm{~g}$ of powdered stem bark is boiled in $500 \mathrm{ml}$ of water for 3-4 h till the volume is reduced to half, cooled and $10 \mathrm{~g}$ of jaggery added to the extract and made into pills. Two to three pills a day for 10 days is administered for acute jaundice).

Review of the literature revealed that this rare medicinal plant remained unexplored for many of its claimed pharmacological activities. In the present study, an effort has been made to evaluate the hepatoprotective activity of Pterocarpus santalinus L.f.

\section{Materials and Methods}

\section{Plant material}

Stem bark of Pterocarpus santalinus was collected during the month of January 2003 from the Ayurvedic medicinal garden at Gajanur, Shimoga district (Forest Department of Shimoga). The voucher specimens (BKM-430, BKM-431) were deposited in the department Herbaria, SRNMN College of Applied Sciences, Shimoga for future reference. 


\section{Extraction}

Stem bark was shade dried for a week and powdered mechanically (Sieve No. 10/44). About $250 \mathrm{~g}$ of the powder was extracted with $70 \%$ ethanol for $48 \mathrm{~h}$ using Soxhlet apparatus. The solvent was distilled off at low temperature under reduced pressure using rotary flash evaporator (Buchi, Flawil, Switzerland). The yield was 21\% w/w. Another $250 \mathrm{~g}$ of the powdered material was boiled in distilled water for 30 min, kept for 3 days with intermittent shaking, filtered and concentrated using rotary flash evaporator to obtain the aqueous extract. Both the extracts were dried in desiccator. The yield was $16.2 \% \mathrm{w} / \mathrm{w}$. Both the extracts were subjected to preliminary phytochemical tests. ${ }^{[11]}$

\section{Drug formulations}

Oral suspensions containing $45 \mathrm{mg} / \mathrm{ml}$ and $30 \mathrm{mg} / \mathrm{ml}$ of the aqueous and ethanol stem bark extracts, respectively, were prepared in $1 \% \mathrm{w} / \mathrm{v}$ gum tragacanth.

Animals

Male Wistar albino rats weighing 150-200 g were procured from the National College of Pharmacy, Shimoga and maintained under standard housing conditions. The animals were fed with commercial diet (Hindustan Lever Ltd., Bangalore) and water ad libitum. The study was permitted by the Institutional Animal Ethical Committee with Reg. No. 144/ 1999/CPCSEA/SMG.

Acute toxicity studies

Acute toxicity study was conducted for both the extracts by stair case method. ${ }^{12]}$ One tenth of the $\mathrm{LD}_{50}$ doses were selected for the evaluation of hepatoprotective activity. ${ }^{[13]}$

The animals were divided into five groups of six rats each. Group I served as control and received the vehicle $(1 \mathrm{ml} / \mathrm{kg} /$ day of $1 \% \mathrm{w} / \mathrm{v}$ gum tragacanth p.o. for 14 days). Group II to $\mathrm{V}$ received $0.1 \mathrm{ml} / \mathrm{kg} /$ day of $\mathrm{CCl}_{4}$ i. p. (E-Merck, Mumbai, India) for 14 days. Group III animals received the standard drug silymarin (Ranbaxy Lab, Dewas) in the dose of $100 \mathrm{mg} / \mathrm{kg} /$ day, p.o. for 14 days, while the aqueous and ethanol stem bark extracts of $P$. santalinus were administered to groups IV and $V$ in the dose of $45 \mathrm{mg}$ and $30 \mathrm{mg} / \mathrm{kg} /$ day, p.o. respectively for 14 days. The $\mathrm{CCl}_{4}$ and silymarin or the extracts were administered concomitantly to the respective groups.

All the animals were sacrificed on $14^{\text {th }}$ day under light ether anesthesia. The blood sample from each animal was collected separately in sterilized dry centrifuge tubes by carotid bleeding and allowed to coagulate for $30 \mathrm{~min}$ at $37^{\circ} \mathrm{C}$. The clear serum was separated at $2500 \mathrm{rpm}$ for $10 \mathrm{~min}$ and subjected to biochemical investigations viz., total bilirubin. ${ }^{14]}$ total protein. ${ }^{[15]}$ serum alanine transaminase, aspartate transaminase $^{[16]}$ and alkaline phosphatase. ${ }^{[17]}$

Results of biochemical estimations are reported as mean \pm SEM of six animal in each group. The data were subjected to one-way ANOVA followed by Tukey's multiple comparision test. $\mathrm{P}<0.001$ was considered statistically significant.

\section{Histopathology}

The liver was excised from the animals and washed with the normal saline. The materials were fixed in $10 \%$ buffered neutral formalin for $48 \mathrm{~h}$ and then with bovine solution for 6 $\mathrm{h}$ and processed for paraffin embedding. Sections of $5 \mathrm{~m}$ thickness were taken using a microtome, processed in alcohol-xylene series and were stained with alumhaematoxylin and eosin ${ }^{[18]}$ and subjected to histopathological examination.

\section{Results}

The $\mathrm{LD}_{50}$ of aqueous and ethanol stem bark extracts were found to be $450 \mathrm{mg} / \mathrm{kg}$, b.w. and $300 \mathrm{mg} / \mathrm{kg}$, b.w, respectively. One tenth of these doses (45 mg/kg, b.w. and $30 \mathrm{mg} / \mathrm{kg}$, b.w.) were selected for the evaluation of hepatoprotective activity. Effect of aqueous and ethanol stem bark extracts of Pterocarpus santalinus on $\mathrm{CCl}_{4}$ induced liver damage in rats with reference to biochemical changes in serum is shown in Table 1. The $\mathrm{CCl}_{4}$ treated control group showed a significant increase in serum total bilirubin $(2.45 \pm 0.01)$, alanine transaminase $(1413.00 \pm 1.99)$, aspartate transaminase $(2213.50 \pm 32.79)$ and alkaline phosphatase $(444.33 \pm 1.56)$ and a decrease in total protein $(5.93 \pm 0.01)$ indicating the

\section{Table 1}

Effect of aqueous and ethanol stem bark extract of Pterocarpus santalinus on $\mathrm{CCl}_{4}$ induced hepatotoxicity in rats

\begin{tabular}{|c|c|c|c|c|c|}
\hline Group (N) & $\begin{array}{l}\text { Total bilirubin } \\
\quad(m g / d l)\end{array}$ & $\begin{array}{l}\text { Total protein } \\
\text { (gm\%) }\end{array}$ & $\begin{array}{l}A S T \\
(I U / L)\end{array}$ & $\begin{array}{l}A L T \\
(I U / L)\end{array}$ & $\begin{array}{l}A L P \\
(I U / L)\end{array}$ \\
\hline Control (1\% w/v gum tragacanth p.o.) & $0.44 \pm 0.01$ & $9.44 \pm 0.02$ & $153.52 \pm 1.43$ & $54.08 \pm 1.16$ & $174.99 \pm 1.80$ \\
\hline $\mathrm{CCl}_{4}(0.1 \mathrm{ml} / \mathrm{kg} /$ day i.p. $)$ & $2.45 \pm 0.01^{*}$ & $5.93 \pm 0.01^{*}$ & $2213.50 \pm 32.79^{*}$ & $1413.00 \pm 1.99^{*}$ & $444.33 \pm 1.56^{*}$ \\
\hline $\begin{array}{l}\mathrm{CCl}_{4}+\text { silymarin }(0.1 \mathrm{ml} / \mathrm{kg} / \text { day i.p. } \\
+100 \mathrm{mg} / \mathrm{kg} / \text { day } \text { p.o. })\end{array}$ & $0.54 \pm 0.01^{\dagger}$ & $8.82 \pm 0.01^{\dagger}$ & $208.50 \pm 2.17^{\dagger}$ & $75.18 \pm 1.17^{\dagger}$ & $184.40 \pm 1.16^{\dagger}$ \\
\hline $\begin{array}{l}\mathrm{CCl}_{4}+\text { aqueous extract }(0.1 \mathrm{ml} / \mathrm{kg} / \text { day i.p } \\
+45 \mathrm{mg} / \mathrm{kg} / \text { day p.o. })\end{array}$ & $0.93 \pm 0.02^{\dagger @}$ & $7.40 \pm 0.02^{\dagger @}$ & $242.17 \pm 2.02^{\dagger @}$ & $193.36 \pm 1.49^{\dagger} @$ & $244.30 \pm 1.91^{\dagger}$ \\
\hline $\begin{array}{l}\mathrm{CCl}_{4}+\text { ethanol extract }(0.1 \mathrm{ml} / \mathrm{kg} / \text { day i.p. } \\
+30 \mathrm{mg} / \mathrm{kg} / \text { day p.o. })\end{array}$ & $0.62 \pm 0.01^{\dagger @}$ & $8.41 \pm 0.02^{\dagger @}$ & $221.67 \pm 2.59^{\dagger @}$ & $125.06 \pm 1.27^{\dagger}$ & $204.43 \pm 1.64^{\dagger @}$ \\
\hline One-way & 3282.0 & 8643.0 & 3691.0 & 1.63 & 4659.0 \\
\hline \multirow[t]{2}{*}{ ANOVA } & 4,25 & 4,25 & 4,25 & 4,25 & 4,25 \\
\hline & 0.01 & 0.01 & 0.01 & 0.01 & 0.01 \\
\hline
\end{tabular}

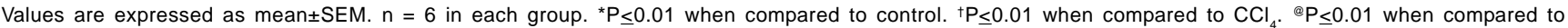
silymarin. 
Figure 1. Section of the liver tissue of control animal showing normal histology and a portal triad showing portal vein (V), hepatic artery (arrow) and bile duct (arrow head). (H \& E, 100X)

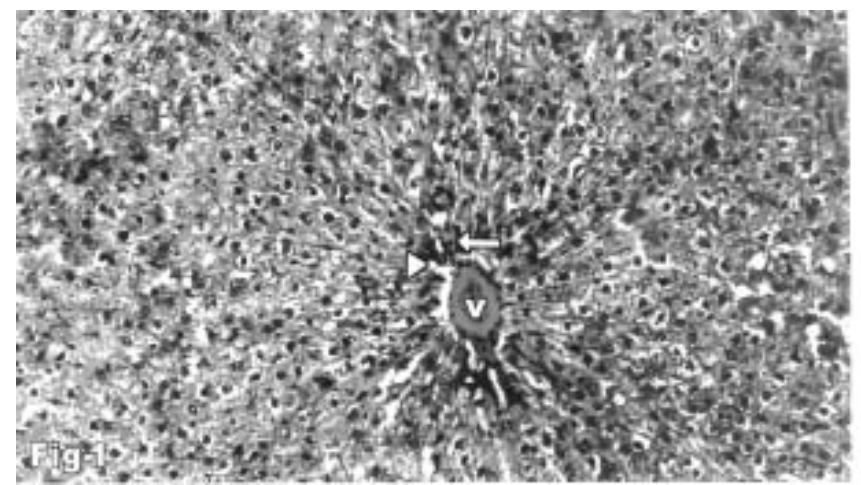

Figure 2. Section of the liver tissue of animal treated with $\mathrm{CCl}_{4}$ showing a central hepatic vein $(\mathrm{V})$, necrosis $(\mathrm{N})$ and fatty change (F). (H \& $E, 100 X)$

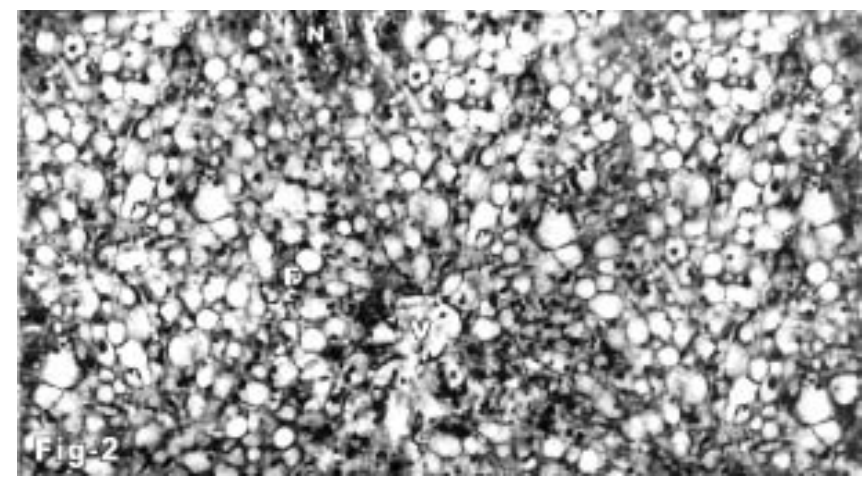

Figure 3. Section of the liver tissue of silymarin treated animals showing normal hepatocytes with central hepatic vein $(V)$. (H \& $E$, 100X)

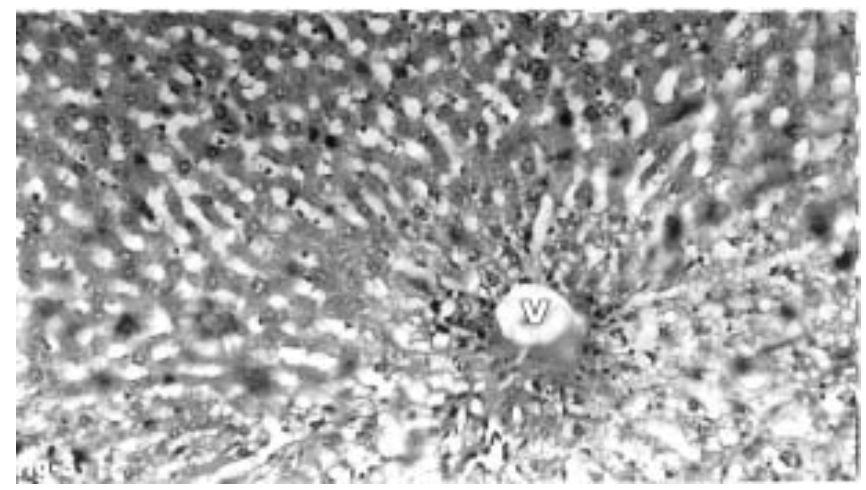

Figure 4. Section of the liver tissue of aqueous stem bark extract treated animals showing normal arrangement of hepatocytes around the portal vein $(\mathrm{V})$, hepatic artery (arrow), bile duct (arrow head), absence of necrosis and few fatty vacuoles. (H \& E, 100X)

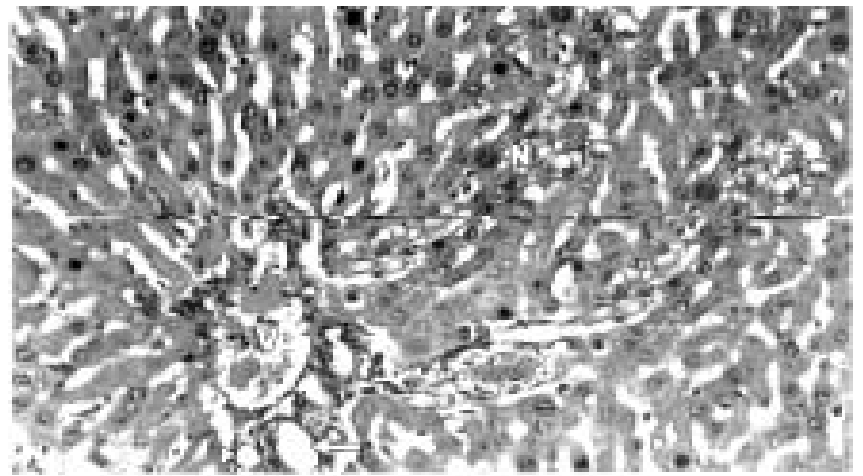

Figure 5. Section of the liver tissue of ethanol stem bark extract treated animals showing normal arrangement of hepatocytes around the portal vein $(\mathrm{V})$, hepatic artery (arrow), bile duct (arrow head), absence of necrosis and fatty vacuoles. (H \& E, 100X)

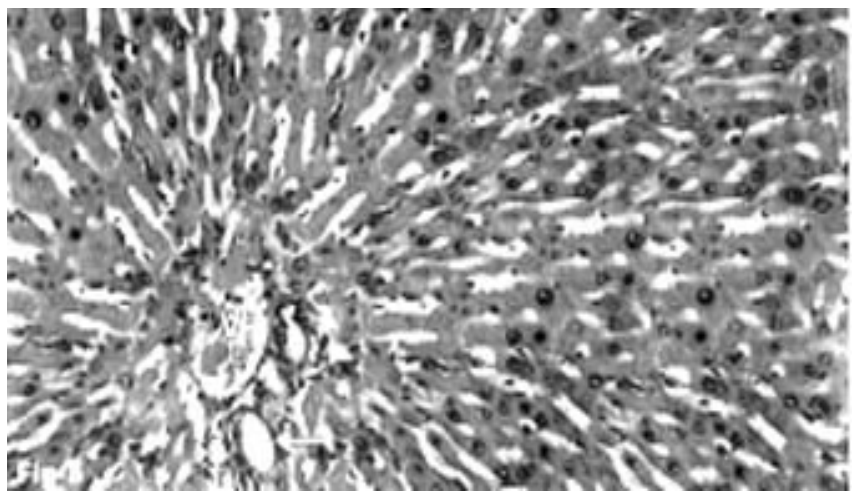

liver injury caused by $\mathrm{CCl}_{4}$. Whereas animals treated with aqueous and ethanol stem bark extracts exhibited a decrease in total bilirubin $(0.93 \pm 0.02 ; 0.62 \pm 0.01)$, alanine transaminase $(193.36 \pm 1.49 ; 125.06 \pm 1.27)$, aspartate transaminase $(242.17 \pm 2.02 ; 221.67 \pm 2.59)$ and alkaline phosphatase $(244.30 \pm 1.91 ; 204.43 \pm 1.64)$ along with a significant increase in total protein $(7.40 \pm 0.02 ; 8.41 \pm 0.02)$.

Histologically, control animals showed normal hepatic architecture (Figure 1), -the group II animals exhibited intense centrilobular necrosis $(\mathrm{N})$, vacuolization and macrovesicular fatty changes (F) (Figure 2). Silymarin treated animals showed a normal hepatic architecture (Figure 3). Moderate accumulation of fatty lobules and cellular necrosis (Figure 4) were observed in the animals treated with aqueous extract. However, the ethanol extract treated animals exhibited significant liver protection against $\mathrm{CCl}_{4}$ induced liver damage, as evident by the presence of normal hepatic cords, absence of necrosis and fatty infiltration (Figure 5). 


\section{Discussion}

The present investigation indicated that both the extracts of Pterocarpus santalinus provide significant protection against $\mathrm{CCl}_{4}$ induced hepatotoxicity in rats. $\mathrm{CCl}_{4}$ is widely used as hepatotoxin in the experimental studies. The $\mathrm{CCl}_{4}$ is biotransformed by the cytochrome $\mathrm{P} 450$ system to produce the trichloromethyl free radicals, which in turn covalently binds to cell membranes and organelles to elicit lipid peroxidation. ${ }^{[19]}$ Several plants viz., Cassia aungustifolia, ${ }^{[20]}$ Wrightia tinctoria, ${ }^{[21]}$ Foeniculum vulgare ${ }^{[22]}$ and Panax notoginseng ${ }^{[23]}$ have been tested for their efficacy in controlling the $\mathrm{CCl}_{4}$ induced liver damage. Further it has been evident that several phytoconstituents have the ability to induce microsomal enzymes either by accelerating the excretion of $\mathrm{CCl}_{4}$ or by inhibition of lipid peroxidation induced by $\mathrm{CCl}_{4}{ }^{|24|}$ Phytoconstituents like flavonoids, ${ }^{[25]}$ triterpenoids, ${ }^{[26]}$ saponins $^{|27|}$ and alkaloids ${ }^{|28|}$ are known to possess hepatoprotective activity. Phytochemical investigations of aqueous and ethanol extract of stem bark revealed the presence of alkaloids, phenols, saponins, glycosides, flavonoids, triterpenoids, sterols and tannins. The present study revealed that among the two extract tested, ethanol extract of stem bark of $P$. santalinus found to possess significant protective effect against hepatotoxicity induced by carbon tetrachloride which may be attributed to the individual or combined action of phytoconstituents present in it. The component(s) of the extract responsible for this effect however was not investigated. Further investigations are needed for identification of the active compounds responsible for hepatoprotective activity. The present finding provides scientific evidence to the ethnomedicinal use of this rare plant genetic resource by the tribal group of Western Ghats in treating jaundice.

\section{Acknowledgements}

The author is grateful to Sri. Girimaji N. Rajgopal, Secretary, Sri. S.V. Thimmaiah, Joint Secretary, Prof. Darmanada Rao, Registrar, National Education Society, Shimoga, S.M. Vidya, S.R.N.M.N. College of Applied Sciences, Shimoga, Dr.V.Krishna, Dept. of Biotechnology, Kuvempu University and Prof. K.L. Mankani, Prof. Y.N. Manohara and S.D. Jagadeesh Singh, National College of Pharmacy, Shimoga.

\section{References}

1. Anuradha M, Pullaiah T. Propagation studies of red sanders (Pterocarpus santalinus L.f.) in vitro an endangered taxon of Andra Pradesh, India. Taiwania 1999;44:311-24.

2. Keshav Reddy K, Srivasuki KP. Vegetative propagation of red sanders (Pterocarpus santalinus L.f.). Indian Forester 1990;116:536-9.

3. Chopra RN, Nayar SL, Chopra IC. Glossory of Indian Medicinal Plants. New Delhi: C.S.I.R. Publications; 1956.

4. Anonymous. The Wealth of India. New Delhi: C.S.I.R. Publications; 1969.

5. Krishnaveni KS, Srinivasa Rao JV. A new isoflavone glucoside from
Pterocarpus santalinus. Asian Nat Prod Res 2000;2:219-23.

6. Krishnaveni KS, Srinivasa Rao JV. An isoflavone from Pterocarpus santalinus. Phytochem 2000;53:605-6.

7. Krishnaveni KS, Srinivasa Rao JV. A new acylated isoflavone glucoside from Pterocarpus santalinus. Chem Pharm Bull 2000;48:1373-4.

8. Cho JY, Park J, Kim PS, Yoo ES, Baik KU, Park MH. Savinin a lignan from Pterocarpus santalinus inhibits tumor necrosis factor-alpha production and T-cell proliferation. Biol Pharm Bull 2001;24:167-71.

9. Krishnaveni KS, Srinivasa Rao JV. A new triterpene from callus of Pterocarpus santalinus. Fitoter 2000;71:10-3.

10. Kameswara Rao B, Giri R, Kesavulu MM, Apparao C. Effect of oral administration of bark extracts of Pterocarpus santalinus on blood glucose level in experimental animals. J Ethnopharmacol 2001;74:69-74.

11. Kokate CK, Purohith AP, Gokhale SB. Pharmacognosy. Pune, India: Nirali Prakashan; 1990.

12. Ghosh MN. Fundamentals of experimental pharmacology. Calcutta, India: Scientific Book agency; 1984.

13. Jalalpure SS, Patil MB, Prakash NS, Hemalatha K, Manvi FV. Hepatoprotective activity of fruits of Piper longum L. Indian J Pharm Sci 2003;65:363-6.

14. Mallory HT, Evelyn EA. The determination of bilirubin with photoelectric colorimeter. J Biol Chem 1937;119:481-5.

15. Kingsley SR. The determination of serum total protein, albumin and globulin by the Biuret reaction. J Biol Chem 1939;131-7.

16. Reitzman S, Frankel S. A colorimetric method for the determination of serum glutamic oxalo acetic acid, glutamic pyruvic transaminase. Amer J Clin Path 1957;28:56-63.

17. Bessey OA, Lowery DM, Brock MJ. A method for the rapid determination of alkaline phosphatase with five cubic millimeters of serum. $\mathrm{J}$ Biol Chem 1964;164:321-9.

18. Galigher AE, Kayloff EN. Essentials of practical microtechniques. Philadelphia: Lea and Febiger; 1971.

19. Recknagel RO, Glende EA, Dolak JA Jr, Waller RLC. Mechanism of carbon tetrachloride toxicity. Pharmacol Ther 1989;43:139-54.

20. Ilavarasan R, Mohideen S, Vijayalakshmi M, Manonmani G. Hepatoprotective effect of Cassia angustifolia Vahl. Indian J Pharm Sci 2001;63:504-7.

21. Chandrashekhar VM, Abdul Haseeb TS, Habbu PV, Nagappa AN. Hepatoprotective activity of Wrightia tinctoria (Roxb) in rats. Indian Drugs 2004;41:366-70.

22. Ozbek H, Ugras S, Bayram I, Tuncer I, Ozturk G, Ozturk A. Hepatoprotective effect of Foeniculum vulgare essential oil. Fitoter 2003;74:317-9.

23. Yoshikawa M, Morikawa T, Kashima Y, Ninomiya K, Matsuda H. Structure of new dammarane-type triterpene saponins from the flower buds of Panax notoginseng and hepatoprotective effects of principal ginseng saponins. $J$ Nat Prod 2003;66:922-4.

24. Mehta RS, Shankar MB, Geetha M, Saluja AK. Hepatoprotective activity of Trianthema portulacastrum. Indian Drugs 1999;36:241-4.

25. Baek NL, Kim YS, Kyung JS, Park KH. Isolation of anti-hepatotoxic agent from the roots of Astragalus membranaceous. Korean J Pharmacog 1996;27:111-6.

26. Xiong X, Chen W, Cui J, Yi S, Zhang Z, Li K. Effects of ursolic acid on liver protection and bile secretion. Zhong Yao Cai 2003;26:578-81.

27. Tran QI, Adnyana IK, Tezuka Y, Nagaoka T, Tran QK, Kadota S. Triterpene saponins from Vietnamese ginseng (Panax vietnamensis) and their hepatocyteprotective activity. J Nat Prod 2001;64:456-61.

28. Vijyan P, Prashanth HC, Dhanaraj SA, Badami S, Suresh B. Hepatoprotective effect of total alkaloid fraction of Solanum pseudocapsicum leaves. Pharmaceut Biol 2003;41:443-8.

\section{Join "IndPharm" \\ IJP uses "IndPharm" to broadcast announcements. Want to join? Please E-mail: adithan@vsnl.com}

